\title{
Mechanisms of Action of Currently Prescribed and Newly Developed Antiepileptic Drugs
}

\author{
${ }^{*} \dagger$ Robert L. Macdonald and *Kevin M. Kelly \\ Departments of *Neurology and +Physiology, University of Michigan Medical School, Ann Arbor, Michigan, U.S.A.
}

Summary: Clinically available antiepileptic drugs (AEDs) decrease membrane excitability by interacting with neurotransmitter receptors or ion channels. AEDs developed before 1980 appear to act on sodium (Na) channels, $\gamma$-aminobutyric acid $_{A}\left(G_{A B A}\right)$ receptors, or calcium (Ca) channels. Benzodiazepines and barbiturates enhance GABA $_{\text {A }}$-receptor-mediated inhibition. Phenytoin, carbamazepine and, possibly, valproate (VPA) decrease high-frequency repetitive firing of action potentials by enhancing Na channel inactivation. Ethosuximide and VPA reduce a low threshold (T-type) Ca-channel current. The mechanisms of action of recently developed AEDs are less clear. Lamotrigine may decrease sustained high- frequency repetitive firing of voltage-dependent $\mathrm{Na}$ action potentials, and gabapentin (GBP) appears to bind to a specific binding site in the CNS with a restricted regional distribution. However, the identity of the binding site and the mechanism of action of GBP remain uncertain. The antiepileptic effect of felbamate may involve interaction at the strychnine-insensitive glycine site of the $N$-methyl-D-aspartate receptor, but the mechanism of action is not yet proven. Key Words: AnticonvulsantsPhenytoin-Carbamazepine-Barbiturates-Benzodiazepines-Valproate-Ethosuximide-LamotrigineGabapentin-Felbamate.
A limited number of antiepileptic drugs (AEDs) currently are available for use in treatment of patients with epilepsy: phenytoin (PHT), carbamazepine (CBZ), barbiturates and primidone (PRM), benzodiazepines (BZDs), valproate (VPA), ethosuximide (ESM), and trimethadione (TMO). Recently, several additional AEDs have or will soon become available, the most promising of which are lamotrigine (LTG), gabapentin (GBP), and felbamate (FBM). It is likely that these standard and new AEDs have as their primary targets of action neurotransmitter receptors or ion channels, primarily $\gamma$-aminobutyric $\operatorname{acid}_{A}\left(\mathrm{GABA}_{\mathrm{A}}\right)$-receptor channels, voltage-dependent sodium $(\mathrm{Na})$ channels, and voltage-dependent calcium ( $\mathrm{Ca}$ ) channels. The basic action of the identified AEDs on neurotransmitter receptor channels or ion channels may be responsible for their clinical actions; these interactions are the subject of this review.

Address correspondence and reprint requests to $\mathrm{Dr}$. R. L. Macdonald at Neuroscience Laboratory Building, 1103 East Huron, Ann Arbor, MI 48104-1687, U.S.A.

\section{BZDs AND BARBITURATES}

BZDs and barbiturates enhance GABAergic inhibition at free-serum concentrations found in ambulatory patients (Macdonald, 1989). Both BZDs and barbiturates interact with the $\mathrm{GABA}_{\mathrm{A}}$ receptor (GABAR), which is a macromolecular protein containing binding sites for, at least, GABA, picrotoxin, neurosteroids, barbiturates, and BZDs, and with a chloride $\left(\mathrm{Cl}^{-}\right)$ion-selective channel (DeLorey and Olsen, 1992). GABARs appear to be composed of combinations of different subtypes $(\alpha 1-\alpha 6$, $\beta 1-\beta 4, \gamma 1-\gamma 3, \delta$, and $\rho 1-\rho 2$ ) of polypeptide subunits (Schofield et al., 1987; Pritchett et al., 1989a; Shivers et al., 1989; Cutting et al., 1991). Table 1 contains a summary of some biochemical properties of the different GABAR subunit subtypes, which all share similar structural features and basic functional properties. There is a differential regional expression in the CNS and spinal cord of various subunit subtype messenger RNAs (mRNAs) (Laurie et al., 1992; Wisden et al., 1992). Some subtype mRNAs were expressed only in specific cell types ( $\alpha 6$ mRNA was demonstrated only in cerebellar granule cells), whereas other subtype mRNAs, such 
TABLE 1. GABAR subunit subtype biochemistry

\begin{tabular}{lccccc}
\hline \multicolumn{1}{c}{ Subunits } & $\alpha$ & $\beta$ & $\gamma$ & $\delta$ & $\rho$ \\
\hline No. of subtypes & 6 & 4 & 3 & 1 & 2 \\
No. of splice variants & 0 & 1 & 1 & 0 & 0 \\
AA sequence size range (kDa) & $48-64$ & 51 & 48 & 48 & 52 \\
\% AA homology intrafamily & $70-80$ & $70-80$ & $70-80$ & NA & $70-80$ \\
\% AA homology interfamily & $30-40$ & $30-40$ & $30-40$ & $30-40$ & $30-40$ \\
\hline
\end{tabular}

GABAR, $\gamma$-aminobutyric acid $_{A}$ receptor; kDa, kilodalton; AA, amino acid; NA, not applicable. From Macdonald and Olsen, 1994.

as for the $\beta 2$ subtype, had a more widespread distribution. Therefore, differential expression and assembly of various subunit subtypes could produce a multitude of GABAR isoforms.

GABA binds to GABARs to regulate gating (opening and closing) of the $\mathrm{Cl}$ ion channel. The single-channel gating properties of the mainconductance state of the native GABAR in murine spinal cord neurons in culture have been characterized (Macdonald et al., 1989a; Weiss and Magleby, 1989; Twyman et al., 1990). Binding of GABA increases the probability of channel opening, and the open channel can close and rapidly reopen to create bursts of openings. To explain this complex gating behavior, the single-channel activity of the main conductance state has been modeled using a reaction scheme that incorporates 2 sequential GABA binding sites, 3 open states, and 10 closed states (Macdonald et al., 1989a; Twyman et al., 1990).

Barbiturates and BZDs can modulate GABAR current by regulating the single-channel properties of the receptor. To enhance the current, a drug may increase the channel conductance, increase the channel open-and-burst frequencies, and/or increase the channel open-and-burst durations. The kinetic model of the GABAR has been used to study the mechanisms of action of AEDs that act on the GABAR.

Barbiturates enhance the GABAR current by binding to an allosteric regulatory site on the receptor (Olsen, 1987). Results from fluctuation analysis suggest that phenobarbital and pentobarbital increase the mean channel-open duration of GABAR currents without altering channel conductance (Study and Barker, 1981). Single-channel recordings of barbiturate-enhanced single GABAR currents directly demonstrate that barbiturates increase mean channel-open duration but do not alter receptor conductance or opening frequency (Macdonald et al., 1989b; Twyman et al., 1989).

For $\alpha 1 \beta 1$ receptors expressed in Xenopus oocytes or Chinese hamster ovary (CHO) cells, currents were increased by pentobarbital (Moss et al., 1990; Verdoorn et al., 1990). Furthermore, the concentration dependence for the effect was the same for receptors with different $\alpha$ and $\beta$ subunits coexpressed with $\gamma 2$ and with $\beta 2 \gamma 2$ alone in Xenopus oocytes (Verdoorn et al., 1990). These results directly demonstrate that the $\alpha$ and $\beta$ subunits contain the allosteric regulatory site for barbiturates.

GABARs have a high-affinity binding site for BZDs, and BZD and GABAR binding sites have been demonstrated to be allosterically coupled (Olsen, 1987). BZDs increase GABAR current. Results from fluctuation analysis suggest that the $B Z D$ diazepam increases GABAR current by increasing opening frequency without altering channel conductance or open duration (Study and Barker, 1981). Single-channel recordings have confirmed that BZDs increase receptor-opening frequency without aitering mean open time or conductance (Vicini et al., 1987; Rogers et al., 1989).

The GABARs expressed in Xenopus oocytes and $\mathrm{CHO}$ cells formed from $\alpha 1 \beta 1$ subunits are insensitive to BZDs (Pritchett et al., 1989b; Moss et al., 1990). The basis for this insensitivity was determined when two forms of a third GABAR subunit, the $\gamma$ and $\gamma 2$ subunits, were isolated from a human fetal brain complementary DNA (cDNA) library (Pritchett et al., 1989b). When the $\gamma 2$ subunit was transiently coexpressed with $\alpha 1$ and $\beta 1$ subunits in human embryonic kidney cells, fully functional GABARs were formed that were sensitive to BZDs, $\beta$-carbolines, barbiturates, and picrotoxin.

Analysis of binding of various BZDs to purified GABARs from brain regions revealed the existence of two subclasses of BZD binding sites, type I and type II (Klepner et al., 1978; Braestrup et al., 1981; Lipa et al., 1981; Garret et al., 1985; Eichinger and Sieghart, 1986). The basis for this heterogeneity was clarified after the identification of multiple GABAR subunit families. The molecular basis of types I and II BZD-binding sites was determined using transient expression of $\alpha \mathrm{x}(\mathrm{x}=1-6) \beta 1 \gamma 2 \mathrm{~S}$ subunit combinations in human embryonic kidney 293 cells (Pritchett et al., 1989a; Pritchett and Seeberg, 1990). The combination of $\alpha 1 \beta 1 \gamma 2 S$ GABAR subtypes produced type I BZD-binding sites, and expression of $\alpha 2 \beta 1 \gamma 2 S, \alpha 3, \beta 1 \gamma 2 S$, or $\alpha 5 \beta 1 \gamma 2 S$ GABAR subtype combinations produced type II 
BZD-binding sites. These receptor isoforms were differentiated based on binding of the type I BZDselective compounds, zolpidem and CL 218872. Expression of the $\alpha 4$ or $\alpha 6$ subtype with $\beta 1$ and $\gamma 2 S$ subtypes produced less-characterized BZD-binding sites, thought previously to be an artifact (Sieghart et al., 1987; Wisden et al., 1991). These receptor isoforms did not bind the prototypical BZDs, diazepam and flunitrazepam, or $\beta$-carbolines, but did bind the "alcohol antagonist" Ro 15-4513 and the BZD antagonist flumazenil (Ro 15-1788). Binding of GABA agonists (muscimol) was not impaired. BZD receptor pharmacology was not altered by substituting any other $\beta$ subtype. Therefore, BZD pharmacology of recombinant GABARs appeared to depend on the $\alpha$ subtype. The original types I and II BZD classification was further segregated into type I ( $\alpha 1)$, type IIA ( $\alpha 2$ and $\alpha 3$ ), type IIB ( $\alpha 5)$, and type III ( $\alpha 4$ and $\alpha 6)$ BZD sites (Pritchett et al., 1989a; Doble and Martin, 1992). Therefore, despite the finding that the $\gamma$ subunit confers BZD sensitivity to GABARs, the $\alpha$ subunit appears to determine the type of BZD receptor expressed.

\section{PHT AND CBZ}

In patients being treated for epilepsy, PHT and $\mathrm{CBZ}$ have been shown to interact with voltagedependent $\mathrm{Na}$ channels at concentrations found free in plasma (Macdonald, 1989). These AEDs were demonstrated to reduce the frequency of sustained repetitive firing of action potentials in neurons in cell culture (McLean and Macdonald, 1983, $1986 b$ ). Their characteristic property was no reduction of the amplitude or duration of single action potentials but reduction of the ability of neurons to fire trains of action potentials at high frequency. The limitation of high-frequency repetitive firing was voltage dependent, with limitation of firing increased after depolarization and reduced after hyperpolarization. Once developed, the limitation of firing was prolonged, lasting several hundred milliseconds. AED action appeared to be caused by a shift of $\mathrm{Na}$ channels to an inactive state that was similar to the normally occurring inactive state but from which recovery was delayed.

The actions of PHT and CBZ also have been studied on mammalian myelinated nerve fibers (Schwarz and Grigat, 1989). Both drugs produced a voltage-dependent block of $\mathrm{Na}$ channels that could be removed by hyperpolarization. PHT produced a shift of the steady-state Na-channel inactivation curve to more negative voltages. PHT and CBZ both reduced the rate of recovery of $\mathrm{Na}$ channels from inactivation. In control solutions, Na channels recovered from complete inactivation in a few milliseconds after a 500-ms depolarization to $25 \mathrm{mV}$. In the presence of $100 \mu M$ PHT or CBZ, recovery was prolonged to 90 or $40 \mathrm{~ms}$, respectively. At $50 \mu M$, PHT and CBZ each produced a frequencydependent block. At $50 \mu M$, PHT produced an initial block of $50 \%$. With repetitive stimulation at 10 $\mathrm{Hz}$, the block increased to about $80 \%$ over $2.5 \mathrm{~s}$. Recovery from this block required approximately $2.5 \mathrm{~s}$. At $100 \mu M, \mathrm{CBZ}$ also produced a frequencydependent block that was somewhat less pronounced than that produced by PHT. Thus, PHT and CBZ produced voltage- and frequencydependent block of $\mathrm{Na}$ channels. Because the concentration-response curves could be fitted assuming a first-order reaction, it was suggested that one drug molecule binds to one receptor near or at the $\mathrm{Na}$ channel. The data are also consistent with PHT and CBZ binding with higher affinity to inactivated $\mathrm{Na}$ channels than to open or resting $\mathrm{Na}$ channels. Of interest was the finding that PHT had a longer time dependence for frequency-dependent block and for recovery from block than did CBZ, resulting in a more pronounced frequency-dependent block for PHT than for CBZ. Therefore, although PHT and CBZ have qualitatively similar actions on $\mathrm{Na}$ channels, the actions are quantitatively somewhat different. This may explain, at least in part, differences in efficacy for these two AEDs in different patients.

Similar voltage-clamp experiments were performed on isolated mammalian brain neurons (Wakamori et al., 1989). Hippocampal pyramidal neurons from the CA1 region were obtained from 1and 2-week-old rats. At $200 \mu M$, PHT produced a 20-mV negative shift in the steady-state inactivation curve for $\mathrm{Na}$ channels and produced frequencydependent block of $\mathrm{Na}$ channels. Frequencydependent block was shown at frequencies as low as $1 \mathrm{~Hz}$; the block increased to $50 \%$ at $10 \mathrm{~Hz}$. Therefore, the ability of PHT to enhance inactivation in neurons in cell culture and in mammalian myelinated nerve fibers also was present in isolated mammalian neurons.

The effect of PHT on human Na channels has also been examined (Tomaselli et al., 1989). Total mRNA was extracted from human brain and injected into Xenopus oocytes. The human brain Na channels expressed in oocytes were also blocked by PHT in a voltage-, frequency-, and time-dependent fashion. The effects of PHT on human Na channels were very similar to those on cultured mouse neurons, rat myelinated nerve, and rat hippocampal pyramidal neurons.

Evidence from voltage-clamp experiments has 
therefore confirmed the basic mechanism of action of PHT and CBZ. Both appear to stabilize the inactive form of the $\mathrm{Na}$ channel in a voltagedependent fashion, the effect being lessened at large negative membrane potentials and increased at less negative membrane potentials. Both AEDs slow the rate of recovery from $\mathrm{Na}$-channel inactivation and shift the steady-state Na-inactivation curve to more negative voltages. This stabilization of the inactive form of the receptor results in a frequencydependent block of $\mathrm{Na}$ channels and in the blockade of sustained high-frequency repetitive firing of action potentials evoked from reduced membrane potentials. It is notable that PHT has a stronger slowing effect than CBZ; therefore, these AEDs have slightly different actions under different conditions of repetitive firing.

\section{ESM AND TMO}

A number of AEDs have been demonstrated to modify the properties of voltage-dependent $\mathrm{Ca}$ channels (Macdonald, 1989b). PHT, barbiturates, and BZDs reduce $\mathrm{Ca}$ influx into synaptic terminals and block presynaptic release of neurotransmitter. However, these actions have been demonstrated only at concentrations that are above therapeutic free-serum concentrations in patients treated for epilepsy. Therefore, it has been concluded that the primary actions of AEDs are not on Ca channels. $\mathrm{Ca}$ channels, however, have been shown to be heterogeneous (Snutch et al., 1990, 1991; Hui et al., 1991; Mori et al., 1991; Starr et al., 1991; Williams et al., 1992). At least four different types of voltagedependent $\mathrm{Ca}$ channels have been described: L-type, T-type, N-type, and P-type (Nowycky et al., 1985; Mintz et al., 1992). These four Ca channels have different voltage ranges for activation and inactivation and different rates of activation and inactivation. Each channel type has been cloned and shown to be composed of several subunits: L-type channel (Campbell et al., 1988; Catterall, 1988); N-type channel (Williams et al., 1992; Fujita et al., 1993); P-type channel (Mori et al., 1991); and T-type channel (Soong et al., 1993). In addition, many subtypes of channels have been identified. It is also likely that these are not the only types of $\mathrm{Ca}$ channels present on neurons.

In view of the finding that neurons express multiple Ca channels, it may be that AEDs act on specific types of channels. Indeed, this has been demonstrated for ESM, TMO, and VPA, which are effective in the treatment of generalized absence seizures. Generalized absence epilepsy is characterized clinically by brief periods of loss of con- sciousness and electrically by a generalized $3-\mathrm{Hz}$ spike-and-wave EEG discharge. It has been suggested that thalamic relay neurons play a critical role in the generation of the abnormal thalamocortical rhythmicity that underlies the $3-\mathrm{Hz}$ spike-andwave discharge. Whole-cell voltage-clamp recordings from acutely dissociated relay neurons from rat thalamus have demonstrated the presence of lowthreshold (T-type) and high-threshold Ca currents (Coulter et al., 1989a). The T-type currents had properties such that $T$-channel activation was necessary and sufficient to cause the generation of lowthreshold $\mathrm{Ca}$ spikes in thalamic relay neurons. It was demonstrated that both ESM and dimethadione, the active metabolite of TMO, reduced the T-type current of thalamic neurons isolated from guinea pigs and rats (Coulter et al., 1989b,c). The reduction of the T-type current was produced at clinically relevant concentrations of ESM and dimethadione. PHT and CBZ, which are ineffective in the control of generalized absence seizures, had minimal effects on T-type current. The ESMinduced reduction of the T-type current was voltage-dependent. The reduction was most prominent at negative membrane potentials and less prominent at more positive membrane potentials. ESM did not alter the voltage dependency of steady-state inactivation or the time course of recovery from inactivation. Dimethadione reduced T-type current by a mechanism similar to that of ESM. Another antiepileptic succinimide, $\alpha$-methyl- $\alpha$-phenylsuccinimide, also reduced T-type currents, whereas an epileptic succinimide, tetramethylsuccinimide, reduced the T-type current only at very high concentrations (Coulter et al., 1990). These results suggest that anticonvulsant succinimides and dimethadione, compounds effective in the treatment of generalized absence epilepsy, may have their primary action in the reduction of the T-type $\mathrm{Ca}$ current in thalamic relay neurons.

\section{VPA}

The effect of VPA on Na channels has been studied less extensively. Although VPA blocked sustained high-frequency firing of neurons in culture (McLean and Macdonald, 1986a), detailed voltageclamp experiments of VPA actions on Na currents have not been performed. It cannot be determined whether VPA has a mechanism of action similar to that of PHT and CBZ until these studies have been performed.

VPA is one of the most effective AEDs against generalized absence seizures. Interestingly, initial studies of VPA did not demonstrate any effect on 
the T-type Ca current, but subsequently VPA was shown to reduce T-type currents in primary afferent neurons (Kelly et al., 1990). The effect was produced over a concentration range of $100-1,000 \mu M$. However, the magnitude of the effect was modest: a $16 \%$ reduction was seen at $1 \mathrm{mM}$ VPA. It is unclear whether this modest reduction in T-type Ca current is sufficient to explain the effect of VPA on generalized absence seizures. Furthermore, the basis for the discrepancy between the results obtained in rat thalamic neurons and rat primary afferent neurons remains uncertain. It may be that different neuron types have different sensitivities to these AEDs or that the small effect is difficult to characterize. Whether this a relevant mechanism of action for VPA will have to be determined by future investigation.

\section{FBM}

FBM, 2-phenyl-1,3-propanediol dicarbamate, is a dicarbamate with a structure similar to that of meprobamate, an antianxiety agent. In experimental animals, it was effective in blocking seizures induced by maximal electroshock (MES), pentylenetetrazol (PTZ), and picrotoxin (Swinyard et al., 1986). FBM inhibited bicuculline-induced seizures at high concentrations but was ineffective against strychnine-induced seizures (Sofia et al., 1991). These results suggest that FBM increases seizure threshold and prevents the electrical spread of seizure activity (Swinyard et al., 1986). In clinical studies, FBM has been effective for treatment of partial seizures with and without becoming secondarily generalized in adults and for partial and generalized seizures associated with the LennoxGastaut syndrome in children.

FBM has been tested for interaction with the GABAR complex as a possible mechanism of antiepileptic activity. In rat brain cortical membranes, FBM did not affect ligand binding to the GABA-, BZD-, or picrotoxin-binding sites of the GABAR complex. In addition, in radiolabeled $\mathrm{Cl}^{-}$influx studies in cultured mouse spinal cord neurons, FBM did not affect GABA-induced ${ }^{36} \mathrm{Cl}$ influx (Ticku et al., 1991). These results suggest that FBM may not have a direct effect on the GABAR complex. However, FBM in subprotective doses enhanced the protective effects of diazepam against seizures induced by MES, PTZ, and isoniazid, but not by bicuculline, suggesting that it has indirect effects on the GABAR complex or is involved in other mechanisms of action (Gordon et al., 1991). FBM reduced sustained repetitive firing of voltagedependent $\mathrm{Na}$ channels in mouse spinal cord neu- rons, producing $50 \%$ inhibition at $67 \mu \mathrm{g} / \mathrm{ml}$ compared with a control population of neurons, of which $72 \%$ responded with sustained repetitive firing (White et al., 1992). It remains to be determined whether these results indicate a direct interaction of FBM with voltage-dependent Na channels.

FBM has also been tested for a possible effect on excitatory amino acid receptors. It inhibited $N$-methyl-D-aspartate (NMDA)- and quisqualateinduced seizures in mice but did not significantly inhibit MK-801 binding (Sofia et al., 1991). However, FBM has been shown to inhibit the binding of $\left[{ }^{3} \mathrm{H}\right]-5,7-d i c h l o r o k y n u r e n i c ~ a c i d$, a competitive antagonist, at the strychnine-insensitive glycine site of the NMDA receptor (McCabe et al., 1993). FBM also reduced the ability of glycine to enhance NMDA-induced Ca currents in cerebellar granule cells measured by the fluorescent probe indo-1. In other studies, D-serine, a glycine-site agonist, was administered cerebroventricularly in audiogenic seizure-susceptible mice and produced a parallel right shift in the FBM anticonvulsant doseresponse curve (Harmsworth et al., 1993). Although not conclusive, these results suggest that FBM activity at the glycine site of the NMDA receptor may be related to the antiepileptic mechanism of action.

\section{GBP}

GBP, 1-(aminomethyl)cyclohexaneacetic acid, is a cyclic GABA analogue originally designed to mimic the steric conformation of GABA (Schmidt, 1989), to have high lipid solubility that permits penetration of the blood-brain barrier, and to be a centrally active GABA agonist with potential therapeutic value (Rogawski and Porter, 1990). GBP has been shown to have anticonvulsant activity in a variety of animal seizure models (Bartoszyk et al., 1986) and is effective in the treatment of human partial and generalized tonic-clonic seizures.

Despite its demonstrated efficacy, the anticonvulsant mechanism of action of GBP is not known. Early work suggested that GBP may act on GABAergic neurotransmitter systems; studies showed that it protected mice from tonic extension in chemical convulsion models using inhibitors of GABA synthesis (3-mercaptopropionic acid, isonicotinic acid, semicarbazide) or antagonists acting on the $\mathrm{GABA}_{\mathrm{A}}$-receptor complex (bicuculline, picrotoxin) (Bartoszyk et al., 1983; Bartoszyk and Reimann, 1985). However, subsequent work has not clearly demonstrated a specific effect of GBP on GABAergic neurotransmitter systems. Inhibition of monoamine release by GBP in electrically stimulated rabbit caudate nucleus (Reimann, 1983) and 
rat cortex (Schlicker et al., 1985) was not modified by GABA, baclofen, or bicuculline, suggesting that GBP did not act on $\mathrm{GABA}_{\mathrm{A}}$ or $\mathrm{GABA}_{\mathrm{B}}$ receptors.

Binding experiments in rat brain and spinal cord have shown that GBP has no significant affinity for the $\mathrm{GABA}_{\mathrm{A}}$ or $\mathrm{GABA}_{\mathrm{B}}$ binding sites measured by $\left[{ }^{3} \mathrm{H}\right]$ muscimol and $\left[{ }^{3} \mathrm{H}\right]$ baclofen displacement, respectively. GBP did not significantly inhibit the binding of $\left[{ }^{3} \mathrm{H}\right]$ diazepam, had only a weak inhibitory effect on the GABA-degrading enzyme GABAaminotransferase, did not elevate GABA content in nerve terminals, and did not affect the GABA uptake system (Bartoszyk et al., 1986). However, GBP has been shown to increase GABA turnover in several regions of rat brain (Loscher et al., 1991). Recent work has shown that GBP binds to the novel high-affinity site in the CNS (Hill et al., 1993; Suman-Chauhan et al., 1993) and is potently displaced by the anticonvulsant 3-isobutyl GABA (Taylor et al., 1993), but the identity of this binding site remains uncertain. In addition, GBP has been shown to be a substrate for a saturable $\mathrm{L}$-amino acid transport system in rat gut tissues (Stewart et al., 1993). These latter findings raise the possibility of an active transport process of GBP across neuron membranes.

In electrophysiologic studies, GBP did not affect depolarizations elicited by iontophoretic application of GABA on cultured mouse spinal cord neurons (Taylor et al., 1988; Rock et al., 1993). In addition, GBP appeared to act by GABAR-independent mechanisms in studies with rat hippocampal slices (Haas and Wieser, 1986) and the feline trigeminal nucleus (Kondo et al., 1991). GBP has been shown to decrease inhibition evoked by paired-pulse orthodromic stimulation of pyramidal neurons in the hippocampal slice preparation (Dooley et al., 1985; Taylor et al., 1988); however, the specific effect of GBP is not known.

GBP protected mice from convulsions caused by strychnine, a glycine-receptor antagonist, but was unable to displace $\left[{ }^{3} \mathrm{H}\right]$ strychnine in binding studies at the highest concentrations tested (Bartoszyk et al., 1986). Electrophysiologic studies showed no effect of GBP on the response of spinal cord neurons to iontophoretically applied glycine (Rock et al., 1993).

GBP has been tested in animal seizure models where seizures are induced by administration of excitatory amino acids. GBP prolonged the onset latency of clonic convulsions and tonic extension and death in mice after i.p. injections of NMDA, but not of kainic acid or quinolinic acid. GBP did not have a clear effect on convulsions when these compounds or glutamate were injected into the lateral ventricle of rats (Bartoszyk, 1983). The i.p. injections in mice of GBP or the NMDA-receptor competitive antagonist 3-(( \pm$)$-2-carboxypiperazin-4-yl)propyl-1-phosphoric acid (CPP) antagonized tonic seizures. The effect of GBP, but not of CPP, was dose-dependently antagonized by the administration of serine, an agonist at the glycine receptor on the NMDA receptor complex, suggesting an involvement of the strychnine-insensitive glycine site of the NMDA receptor in the anticonvulsant activity of GBP (Oles et al., 1990).

In unpublished studies cited by Chadwick (1992), GBP reportedly antagonized NMDA-induced, but not kainate-induced, depolarizations in thalamic and hippocampal slice preparations, and antagonized NMDA-induced currents in the presence of glycine in cultured striatal neurons, an effect that was reversed by addition of serine or increased glycine. Other studies did not show a significant effect of GBP on neuronal responses to iontophoretic application of glutamate or on membrane depolarizations and single-channel currents evoked by NMDA with or without coapplication of glycine (Rock et al., 1993). These results, in part, are similar to the findings of others, in which GBP had no effect on spinal cord neuron depolarizations elicited by iontophoretically applied glutamate (Taylor et al., 1988) or pressure-ejected NMDA (Wamil et al., 1991a). In addition, in extracellular recordings from rat hippocampal slice preparations, GBP had no effect on long-term potentiation, making it unlike NMDA-receptor antagonists (Taylor et al., 1988).

GBP had no effect on sustained repetitive firing of action potentials in mouse spinal cord neurons (Taylor et al., 1988; Rock et al., 1993). In other experiments using the same neuron preparation, high concentrations of GBP $(100 \mu M)$ reduced sustained repetitive firing of action potentials. After overnight exposure of the cultures to GBP, sustained repetitive firing of action potentials was reduced by GBP $1 \mu M$ (Wamil et al., 1991b). The significance of these findings is not fully established at this time. The different results of the studies done on mouse spinal cord neurons suggest that GBP does not directly interact with voltage-dependent $\mathrm{Na}$ channels or limit sustained repetitive firing of action potentials; therefore, the antiepileptic activity of GBP is not attributable to this mechanism of action.

Although most effective in the treatment of human partial and generalized tonic-clonic seizures, the effect of GBP on absence seizures has been studied in both animal models and as add-on therapy in AED-resistant patients with epilepsy. In animal studies using PTZ-induced clonic seizures, 
GBP protected mice from clonic convulsions in both the subcutaneous Metrazol test and the intravenous threshold test (Bartoszyk et al., 1986). However, in a rat genetic model of absence epilepsy, GBP increased EEG spike-and-wave bursts in a dose-dependent manner (Foot and Wallace, 1991). In human studies, GBP reduced $>50 \%$ of absence seizures in half of the patients in one study (Bauer et al., 1989) and in another study reduced absence seizures and generalized spike-and-wave complexes in patients undergoing 24-h EEG monitoring (Rowan et al., 1989). In studies of mouse spinal cord neurons, GBP blocked responses to Bay $\mathrm{K} 8644$, an agonist at the dihydropyridine binding site of the L-type Ca channel (Wamil et al., 1991a). In other electrophysiologic studies, however, GBP did not significantly affect any $\mathrm{Ca}$-channel current subtype ( $T, N$, or $L$ ), suggesting that the basic mechanism of action was not on voltage-dependent Ca channels (Rock et al., 1993).

In summary, the results of several studies have not demonstrated that GBP has a major effect on ligand- or voltage-gated channels. Further work on the high-affinity binding site of GBP should contribute significantly to understanding its mechanism of action.

\section{LTG}

LTG, 3,5,-diamino-6-(2,3-dichlorophenyl)-astriazine, a phenyltriazine with weak antifolate activity, was developed in response to observations that use of phenobarbital, PRM, and PHT resulted in reduced folate levels, and that folates could induce seizures in experimental animals (Reynolds et al., 1966). Initially, antifolate activity was thought to be related to anticonvulsant activity, but this has not been demonstrated by structure-activity studies (Rogawski and Porter, 1990). LTG has anticonvulsant activity in several animal seizure models, including hind-limb extension in MES and maximal PTZ seizures in rodents (Miller et al., 1986). It has been effective as add-on therapy in the treatment of human partial and generalized tonic-clonic seizures.

The action of LTG on the release of endogenous amino acids from rat cerebral cortex slices in vitro has been studied. LTG potently inhibited release of glutamate and aspartate evoked by the Na-channel activator veratridine and was much less effective in the inhibition of release of acetylcholine or GABA. At high concentrations, LTG had no effect on spontaneous or potassium-evoked amino acid release. These studies suggest that LTG acts at voltagedependent $\mathrm{Na}$ channels, resulting in decreased presynaptic release of glutamate (Leach et al., 1986).
In radioligand studies, the binding of $\left[{ }^{3} \mathrm{H}\right]$ batrachotoxinin A 20- $\alpha$-benzoate, a neurotoxin that binds to receptor site 2 on voltage-dependent $\mathrm{Na}$ channels, was inhibited by LTG in rat brain synaptosomes. In electrophysiologic studies, LTG blocked sustained repetitive firing in cultured mouse spinal cord neurons in a dose-dependent manner at concentrations therapeutic for human seizures (Cheung et al., 1992). These results suggest that the anticonvulsant effect of LTG is due to a specific interaction at the voltage-dependent $\mathrm{Na}$ channel, which may result in a preferential decreased of presynaptic glutamate release.

\section{CONCLUSION}

The currently available AEDs appear to have only three major mechanisms of action (Table 2). Drugs that are effective against generalized tonicclonic and partial seizures appear to reduce sustained high-frequency repetitive firing of action potentials by delaying recovery of $\mathrm{Na}$ channels from activation. AEDs that are effective against generalized absence seizures appear to reduce lowthreshold (T-type) Ca currents. Finally, drugs that are effective against myoclonic seizures generally enhance GABAR inhibition. Although the currently available AEDs have been shown to be effective, there are patients, especially those with complex partial seizures, whose seizures are refractory to these AEDs. FBM, LTG, and GBP have shown promise in clinical trials and may help in managing some refractory patients. Although the mechanisms of action of these drugs are unclear, those of at least GBP and FBM may be novel (Table 3). Furthermore, it is probable that AEDs now under development will have actions on new neurotransmitter receptors or channels. For example, considerable effort has been directed toward developing compounds that are antagonists of excitatory amino acid transmission. With new AEDs that act on different neurotransmitter receptors or channels, it is

TABLE 2. Antiepileptic drug actions

\begin{tabular}{lccc}
\hline & $\begin{array}{c}\mathrm{Na} \\
\text { channels }\end{array}$ & GABAR & $\begin{array}{c}\text { T-Ca } \\
\text { channels }\end{array}$ \\
\hline Carbamazepine & ++ & - & - \\
Phenytoin & ++ & - & - \\
Primidone & + & - & $?$ \\
Valproate & ++ & $? /+$ & $? /+$ \\
Barbiturates & + & + & - \\
Benzodiazepines & + & -+ & - \\
Ethosuximide & - & - & ++ \\
\hline
\end{tabular}

$\mathrm{Na}$, sodium; GABAR, $\gamma$-aminobutyric acid $_{\mathrm{A}}$ receptor; $\mathrm{T}$-Ca, T-type calcium channel. 
TABLE 3. New antiepileptic drug actions

\begin{tabular}{lcccc}
\hline & $\begin{array}{c}\mathrm{Na} \\
\text { channels }\end{array}$ & GABAR & $\begin{array}{c}\text { T-Ca } \\
\text { channels }\end{array}$ & NMDAR \\
\hline Felbamate & + & - & $?$ & + \\
Gabapentin & + & - & - & $?$ \\
Lamotrigine & ++ & - & $?$ & $?$ \\
\hline
\end{tabular}

$\mathrm{Na}$, sodium; GABAR, $\gamma$-aminobutyric $\operatorname{acid}_{\mathrm{A}}$ receptor; $\mathrm{T}$-Ca, T-type calcium channel; NMDAR, $N$-methyl-D-aspartate receptor.

hoped that patients refractory to available AED therapy will become medically treatable.

Approaches to the investigation of the mechanisms of action of AEDs to date have been fairly descriptive. With the recent development of new molecular biologic techniques for the study of CNS function and the cloning of cDNAs for specific neurotransmitter receptors and ion channels that are targets of AEDs, it may be possible to study more closely the interaction of AEDs with their target receptors or channels. This will assist in elucidating channel and receptor structure and may also provide insights into the interactions of AEDs with receptors and channels. Insights gained from these studies may assist in the design of improved AEDs, which may act on the same receptors or channels as standard AEDs but may have more specific or selective actions.

\section{REFERENCES}

Bartoszyk GD. Gabapentin and convulsions provoked by excitatory amino acids. Naunyn Schmiedebergs Arch Pharmacol 1983;324:R24.

Bartoszyk GD, Fritschi E, Herrmann M, Satzinger G. Indications for an involvement of the GABA-system in the mechanism of action of gabapentin. Naunyn Schmiedebergs Arch Pharmacol 1983;322:R94.

Bartoszyk GD, Meyerson N, Reimann W, Satzinger G, von Hodenberg A. Gabapentin. In: Meldrum BS, Porter RJ, eds. Current problems in epilepsy: new anticonvulsant drugs. London: John Libbey; 1986:147-64.

Bartoszyk GD, Reimann W. Preclinical characterization of the anticonvulsant gabapentin. In: Program and abstracts of the 16th Epilepsy International Congress, September 6-9, 1985; Hamburg, Germany: Abstract 1.

Bauer G, Bechinger D, Castell M, et al. Gabapentin in the treatment of drug-resistant epileptic patients. In: Manelis J, Bental E, Loeber JN, Dreifuss FE, eds. The XVIIth epilepsy international symposium. New York: Raven Press; 1989:21921 (Advances in epileptology, vol. 17).

Braestrup C, Nielsen MJ. $\left[{ }^{3} \mathrm{H}\right]$-propyl- $\beta$-carboline-3-carboxylate as a selective radioligand for the BZI benzodiazepine receptor subclass. J Neurochem 1981;37:333-41.

Campbell KP, Leung AT, Sharp AH. The biochemistry and molecular biology of the dihydropyridine-sensitive calcium channel. Trends Neurosci 1988;11:425-30.

Catterall WA. Structure and function of voltage-sensitive ion channels. Science 1988;242:50-61.

Chadwick D. Gabapentin. In: Pedley TA, Meldrum BS, eds. Recent advances in epilepsy. New York: Churchill Livingstone; 1992:211-21.

Cheung H, Kamp D, Harris E. An in vitro investigation of the action of lamotrigine on neuronal voltage-activated sodium channels. Epilepsy Res 1992;13:107-12.

Coulter DA, Hugenard JR, Prince DA. Calcium currents in rat thalamocortical relay neurones: kinetic properties of the transient low-threshold current. J Physiol (Lond) 1989a;414:587604.

Coulter DA, Hugenard JR, Prince DA. Specific petit mal anticonvulsants reduce calcium currents in thalamic neurons. Neurosci Lett 1989b;98:74-8.

Coulter DA, Hugenard JR, Prince DA. Characterization of ethosuximide reduction of low-threshold calcium current in thalamic neurons. Ann Neurol 1989c;25:582-93.

Coulter DA, Hugenard JR, Prince DA. Differential effects of petit mal anticonvulsants and convulsants on thalamic neurones: calcium current reduction. Br J Pharmacol 1990;100: $800-6$.

Cutting GR, Lu L, O'Hara BF, et al. Cloning of the $\gamma$-aminobutyric acid (GABA) $p_{1}$ cDNA: a GABA receptor subunit highly expressed in the retina. Proc Natl Acad Sci USA 1991; 88:2673-7.

DeLorey TM, Olsen RW. $\gamma$-Aminobutyric acid $_{\mathrm{A}}$ receptor structure and function. J Biol Chem 1992;267:16747-50.

Doble A, Martin IL. Multiple benzodiazepine receptors-no reason for anxiety. Trends Pharmacol Sci 1992;13:76-81.

Dooley DJ, Bartoszyk GD, Rock DM, Satzinger G. Preclinical characterization of the anticonvulsant gabapentin. In: Program and abstracts of the 16th Epilepsy International Congress, September 6-9, 1985; Hamburg, Germany: Abstract 8.

Eichinger A, Sieghart W. Postnatal development of proteins associated with different benzodiazepine receptors. $J$ Neurochem 1986;46:173-80.

Foot M, Wallace J. Gabapentin. In: Pisani F, Perucca E, Avazini G, Richens A, eds. New antiepileptic drugs. Amsterdam: Elsevier; 1991:109-14.

Fujita $Y$, Mynlieff M, Kirksen RT, et al. Primary structure and functional expression of the $\omega$-conotoxin-sensitive $\mathrm{N}$-type calcium channel from rabbit brain. Neuron 1993;10:585-98.

Garret KM. Tabakoff B. The development of type I and type II benzodiazepine receptors in the mouse cortex and cerebellum. Pharmacol Biochem Behav 1985;22:985-92.

Gordon R, Gels M, Diamantis W, Sofia RD. Interaction of felbamate and diazepam against maximal electroshock seizures and chemoconvulsants in mice. Pharmacol Biochem Behav $1991 ; 40 ; 109-13$.

Haas HL, Wieser HG. Gabapentin: action on hippocampal slices of the rat and effects in human epileptics. Presented at the Northern European Epilepsy Meeting, 1986; York, U.K., Abstract 9.

Harmsworth WL, Wolf HH, Swinyard EA, White HS. Felbamate modulates glycine receptor function. Epilepsia 1993;34 (suppl 2):92-3.

Hill DR, Suman-Chauhan N, Woodruff GN. Localisation of $\left[{ }^{3} \mathrm{H}\right]$ gabapentin to a novel site in rat brain: autoradiographic studies. Eur J Pharmacol 1993;244:303-9.

Hui A, Ellinor PT, Krizanova O, Wang JJ, Diebold RJ, Schwartz A. Molecular cloning of multiple subtypes of a novel rat brain isoform of the $\alpha_{1}$ subunit of the voltage-dependent calcium channel. Neuron 1991;7:35-44.

Kelly KM, Gross RA, Macdonald RL. Valproic acid selectively reduces the low-threshold $(\mathrm{T})$ calcium in rat nodose neurons. Neurosci Lett 1990;116:233-8.

Klepner CA, Lippa AS, Benson DI, Sano MC, Beer B. Resolution of two biochemically and pharmacologically distinct benzodiazepine receptors. Pharmacol Biochem Behav 1978;11: 457-62.

Kondo T, Fromm GH, Schmidt B. Comparison of gabapentin with other antiepileptic and GABAergic drugs. Epilepsy Res $1991 ; 8: 226-31$.

Laurie DJ, Seeburg PH, Wisden W. The distribution of 13$\mathrm{GABA}_{\mathrm{A}}$ receptor subunit messenger RNAs in the rat brain, 2: olfactory bulb and cerebellum. $J$ Neurosci 1992;12:1063-76.

Leach MJ, Marden CM, Miller AA. Pharmacological studies on lamotrigine, a novel potential antiepileptic drug, II: neuro- 
chemical studies on the mechanism of action. Epilepsia 1986; 27:490-7.

Lipa AS, Beer B, Sano MC, Vogel RA, Myerson LR. Differential ontogeny of type I and type II benzodiazepine receptors. Life Sci 1981;28:2343-7.

Löscher W, Honack D, Taylor CP. Gabapentin increases aminooxyacetic acid-induced GABA accumulation in several regions of rat brain. Neurosci Lett 1991;128:150-4.

Macdonald RL. Antiepileptic drug actions. Epilepsia 1989;30 (suppl 1):S19-28.

Macdonald RL, Olsen RW. GABA A receptor channels. Annu Rev Neurosci 1994;17 (in press).

Macdonald RL, Rogers CJ, Twyman RE. Kinetic properties of the $\mathrm{GABA}_{\mathrm{A}}$ receptor main-conductance state of mouse spinal cord neurones in culture. J Physiol (Lond) 1989a;410:479-99.

Macdonald RL, Rogers CJ, Twyman RE. Barbiturate regulation of kinetic properties of the GABA receptor channel of mouse spinal neurones in culture. J Physiol (Lond) 1989b; 417:483-500.

McCabe RT, Wasterlain CG, Kucharczyk N, Sofia RD, Vogel JR. Evidence of anticonvulsant and neuroprotectant action of felbamate mediated by strychnine-insensitive glycine receptors. J Pharmacol Exp Ther 1993;264:248-52.

McLean MJ, Macdonald RL. Multiple actions of phenytoin on mouse spinal cord neurons in cell cultures. J Pharmacol Exp Ther 1983;227:779-89.

McLean MJ, Macdonald RL. Sodium valproate, but not ethosuximide, produces use- and voltage-dependent limitation of high frequency repetitive firing of action potentials of mouse central neurons in cell culture. J Pharmacol Exp Ther 1986a; 237:1001-11.

McLean MJ, Macdonald RL. Carbamazepine and 10,11epoxycarbamazepine produce use- and voltage-dependent limitation of rapidly firing action potentials of mouse central neurons in cell culture. J Pharmacol Exp Ther 1986b;238: 727-32.

Miller AA, Wheatley P, Sawyer DA, Baxter MG, Roth B. Pharmacological studies on lamotrigine, a novel potential antiepileptic drug, I: anticonvulsant profile in mice and rats. Epilepsia 1986;27:483-9.

Mintz IM, Adams ME, Bean BP. P-Type calcium channels in rat central and peripheral neurons. Neuron 1992;9:85-95.

Mori Y, Friedrich T, Man-Suk K, et al. Primary structure and functional expression from complementary DNA of a brain calcium channel. Nature 1991;350:398-402.

Moss SJ, Smart TA, Porter NM, et al. Cloned GABA receptors are maintained in a stable cell line: allosteric and channel properties. Eur J Pharmacol 1990;189:77-88.

Nowycky MC, Fox AP, Tsien RW. Three types of neuronal calcium channels with different agonist sensitivity. Nature $1985 ; 316: 440-3$.

Oles RJ, Singh L, Hughes J, Woodruff GN. The anticonvulsant action of gabapentin involves the glycine/NMDA receptor. Soc Neurosci Abst 1990;16:783.

Olsen RW. The $\gamma$-aminobutyric acid/benzodiazepine/barbiturate receptor-chloride ion channel complex of mammalian brain. In: Edelman GM, Gall WE, Cowan WM, eds. Synaptic function. New York: John Wiley \& Sons; 1987:257-71.

Pritchett DB, Luddens H, Seeburg PH. Type I and type II $\mathrm{GABA}_{\mathrm{A}}$-benzodiazepine receptors produced in transfected cells. Science 1989a;245:1389-92.

Pritchett DB, Seeburg PH. Gamma-aminobutyric acid receptor $_{\text {A }}$ $\alpha 5$-subunit creates novel type II benzodiazepine receptor pharmacology. J Neurochem 1990;54:1802-4.

Pritchett DB, Sontheimer H, Shivers BD, et al. Importance of a novel $\mathrm{GABA}_{\mathrm{A}}$ receptor subunit for benzodiazepine pharmacology. Nature 1989b;338:582-4.

Reimann W. Inhibition by GABA, baclofen, and gabapentin of dopamine release from rabbit caudate nucleus: are there common or different sites of action? Eur J Pharmacol 1983;94: $341-4$.

Reynolds EH, Milner G, Matthews DM, Chanarin I. Anticon- vulsant therapy, megaloblastic haemopoiesis and folic acid metabolism. QJ Med 1966;35:521-37.

Rock DM, Kelly KM, Macdonald RL. Gabapentin actions on ligand- and voltage-gated responses in cultured rodent neurons. Epilepsy Res 1993;16:89-98.

Rogawski MA, Porter RJ. Antiepileptic drugs: pharmacological mechanisms and clinical efficacy with consideration of promising developmental stage compounds. Pharmacol Rev 1990; 42:223-86.

Rogers CJ, Twyman RE, Macdonald RL. The benzodiazepine diazepam and the beta-carboline DMCM modulate GABA $_{A}$ receptor currents by opposite mechanisms. Soc Neurosci Abst 1989;15:1150.

Rowan AJ, Schear MJ, Wiener JA, Luciano D. Intensive monitoring and pharmacokinetic studies of gabapentin in patients with generalized spike-wave discharges [Abstract]. Epilepsia 1989;30:30.

Schlicker E, Reimann W, Gothert M. Gabapentin decreases monoamine release without affecting acetylcholine release in the brain. Arzneimittelforschung 1985;35:1347-9.

Schmidt B. Potential antiepileptic drugs: gabapentin. In: Levy RH, Driefuss FE, Mattson RH, Meldrum BS, Penry JK, eds. Antiepileptic drugs, 3rd edition. New York: Raven Press; 1989:925-35.

Schofield PR, Darlison MG, Fujita N, et al. Sequence and functional expression of the GABA $\mathrm{A}_{\mathrm{A}}$ receptor shows a ligandgated receptor super-family. Nature 1987;328:221-7.

Schwarz J, Grigat G. Phenytoin and carbamazepine: potentialand frequency-dependent block of $\mathrm{Na}$ currents in mammalian myelinated nerve fibers. Epilepsia 1989;30:286-94.

Shivers BD, Killisch I, Sprengel R, et al. Two novel GABA A receptor subunits exist in distinct neuronal subpopulations. Neuron 1989;3:327-37.

Sieghart W, Eichinger A, Richards JG, Mohler H. Photoaffinity labelling of benzodiazepine receptor proteins with the partial inverse agonist $\left[{ }^{3} \mathrm{H}\right] \mathrm{Ro}$ 15-4513: a biochemical and autoradiographic study. $J$ Neurochem 1987;48:46-52.

Sofia RD, Kramer L, Perhach JL, Rosenberg A. Felbamate. In: Pisani F, Perucca E, Avanzini G, Richens A, eds. New antiepileptic drugs. Amsterdam: Elsevier; 1991:103-8.

Soong TW, Stea A, Hodson CD, Dubel SJ, Vincent SR, Snutch TP. Structure and functional expression of a member of the low voltage-activated calcium channel family. Science 1993; 260:1133-6.

Snutch TP, Leonard JP, Gilbert MM, Lester HA, Davidson N. Rat brain expresses a heterogeneous family of calcium channels. Proc Natl Acad Sci USA 1990;87:3391-5.

Snutch TP, Tomlinson WJ, Leonard JP, Gilbert MM. Distinct calcium channels are generated by alternative splicing and are differentially expressed in the mammalian CNS. Neuron $1991 ; 7: 45-57$.

Starr TVB, Prystay W, Snutch TP. Primary structure of a calcium channel that is highly expressed in the rat cerebellum. Proc Natl Acad Sci USA 1991;88:5621-5.

Stewart BH, Kugler AR, Thompson PR, Bockbrader HN. A saturable transport mechanism in the intestinal absorption of gabapentin is the underlying cause of the lack of proportionality between increasing dose and drug levels in plasma. Pharm Res 1993;10:276-81.

Study RE, Barker JL. Diazepam and (-)-pentobarbital: fluctuation analysis reveals different mechanisms for potentiation of $\gamma$-aminobutyric acid responses in cultured central neurons. Proc Natl Acad Sci USA 1981;78:7180-4.

Suman-Chauhan N, Webdale L, Hill DR, Woodruff GN. Characterisation of $\left[{ }^{3} \mathrm{H}\right]$ gabapentin binding to a novel site in rat brain: homogenate binding studies. Eur J Pharmacol Mol Pharmacol 1993;244:293-301.

Swinyard EA, Sofia RD, Kupferberg HJ. Comparative anticonvulsant activity and neurotoxicity of felbamate and four protype antiepileptic drugs in mice and rats. Epilepsia 1986;27: 27-34.

Taylor CP, Rock DM, Weinkauf RJ, Ganong AH. In vitro and in 
vivo electrophysiology effects of the anticonvulsant gabapentin. Soc Neurosci Abst 1988;14:866.

Taylor CP, Vartanian MG, Yuen PW, Bigge C. Potent and stereospecific anticonvulsant activity of 3-isobutyl GABA relates to in vitro binding at a novel site labeled by tritiated gabapentin. Epilepsy Res 1993;14:11-5.

Ticku MK, Kamatchi GL. Sofia RD. Effect of anticonvulsant felbamate on $\mathrm{GABA}_{\mathrm{A}}$ receptor system. Epilepsia 1991;32: 389-91.

Tomaselli G, Marban E, Yellen G. Sodium channels from human brain RNA expressed in Xenopus oocytes basic electrophysiologic characteristics and their modifications by diphenylhydantoin. J Clin Invest 1989;83:1724-32.

Twyman RE, Rogers CJ, Macdonald RL. Differential regulation of $\gamma$-aminobutyric acid receptor channels by diazepam and phenobarbital. Ann Neurol 1989;25:213-20.

Twyman RE, Rogers CJ, Macdonald RL. Intraburst kinetic properties of the $\mathrm{GABA}_{\mathrm{A}}$ receptor main conductance state of mouse spinal cord neurones in culture. J Physiol (Lond) 1990; 423:193-219.

Verdoorn TA, Draguhn A, Ymer S, Seeburg PH, Sakmann B. Functional properties of recombinant rat GABA receptors depend upon subunit composition. Neuron 1990;4:919-28.

Vicini S, Mienville JM, Costa E. Actions of benzodizapine and $\beta$-carboline derivatives on $\gamma$-aminobutyric acid-activated $\mathrm{Cl}$ channels recorded from membrane patches of neonatal rat cortical neurons in culture. J Pharmacol Exp Ther 1987;243: 1195-1201.

Wakamori M, Kaneda M, Oyama Y, Akaike N. Effects of chlor- diazepoxide, chlorpromazine, diazepam, diphenylhydantoin, flunitrazepam and haloperidol on the voltage-dependent sodium current of isolated mammalian brain neurons. Brain Res 1989;494:374-8.

Wamil AW, McLean MJ, Taylor CP. Multiple cellular actions of gabapentin. Neurology 1991a;41(suppl 1):140.

Wamil AW, Taylor CP, McLean MJ. Effects of gabapentin on repetitive firing of action potentials and GABA responses of mouse central neurons in cell culture. Epilepsia 1991b; 32:20-1.

Weiss DS, Magleby K. Gating scheme for single GABAactivated $\mathrm{Cl}^{-}$channels determined from stability plots, dwell-time distributions, and adjacent-interval durations. $J$ Neurosci 1989;9:1314-24.

White HS, Wolf HH, Swinyard EA, Skeen GA, Sofia RD. A neuropharmacological evaluation of felbamate as a novel anticonvulsant. Epilepsia 1992;33:564-72.

Williams ME, Feldman DH, McCue AF, et al. Structure and functional expression of $\alpha_{1}$ subunits of a novel human neuronal calcium channel subtype. Neuron 1992;8:71-84.

Wisden W, Herb A, Wieland H, Keinanen K, Luddens H, Seeburg PH. Cloning, pharmacological characteristics and expression pattern of the rat $\mathrm{GABA}_{\mathrm{A}}$ receptor $\alpha 4$ subunit. FEBS Lett 1991;289:227-30.

Wisden W, Laurie DJ, Monyer H, Seeburg PH. The distribution

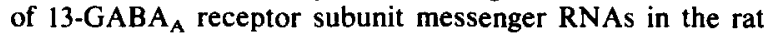
brain: 1 , telencephalon, diencephalon, mesencephalon. $J$ Neurosci 1992;12:1040-62. 